\title{
Determinants of Access to Electronic Banking among Agro-Entrepreneurs in Obio/Akpor L.G.A, Rivers State, Nigeria
}

\author{
Ugwuja V.C, Umeh F. O
}

\begin{abstract}
This study investigated the determinants of access to electronic banking among agro-entrepreneurs in Obio-akpor Local Government Area in Rivers State. The specific objectives were to describe the socio-economic characteristics of Agroentrepreneurs, identify the various electronic banking products accessed by Agro-entrepreneurs, examine the determinants of access to electronic banking among agro-entrepreneurs, examine constraints to accessing electronic banking products among agro-entrepreneurs in the study area. A two-stage sampling procedure was employed in the selection of 80 Agro-entrepreneurs who were accessing electronic banking products and 80 who were not accessing. Data were analysed with descriptive statistics and binary logistic regression. The result showed that $55.8 \%$ were females while $44.2 \%$ were male, married individuals $(56.7 \%)$ were the majority in the study. Most respondents attained secondary education (55.0\%). The study also revealed that majority of E-banking products accessed by agro-entrepreneurs were ATM/Debit card, SMS alert and Balance inquiry.The binary logit regression result on the determinants of access to Electronic banking showed thatEase of use, internet access, reliability, Business experience and perceived security risk were significant factors that influence access e-banking products. Constraints to accessing electronic banking products and services include Long queue at ATM, ATM not dispensing cash all the time and poor internet access. The study recommends that money should be readily available on the ATM to reduce the problem of ATM not always dispensing cash at moments when customers need to access these funds.
\end{abstract}

Index Terms - Agro-entrepreneurs, Electronic Banking, Financial products and services, Rivers State.

\section{INTRODUCTION}

Electronic banking services are a range of banking services or facilities that use electronic devices for financial transactions such as mobile banking, ATM and debit card services, phone banking, SMS banking, electronic alert, fund transfer services, Point of sales banking, E-statements, Other e-commerce or value added services(Abdou, John \& Adewunmi, 2014). Electronic banking system will typically connect to or be part of the core banking system operated by a bank and it is in contrast to branch banking which was the traditional way customers accessed banking services (Abdouet al., 2014).Sharma and Zhang (2012) describe e-banking as an electronic connection between bank and

Ugwuja Vivian Chinelo, Department of Agricultural Economics and Extension, University of Port Harcourt, Nigeria

Umeh Francisca. O, Department of Agricultural Economics and Extension, University of Port Harcourt, Nigeria customer in order to prepare, manage and control financial transactions. According to Tan and Teo (2000), customers insatiable appetite for efficient service had compelled financial institution to move fast to a more radical transformation of their business systems and models by embracing electronic banking. Sharp (2007), stated that rising numbers of financial institutions are introducing and expanding their offerings of electronic banking products. Pikkarainen, Pikkarainen, Karjaluoto, and Pahnila, (2004), indicated that electronic banking services delivery are the cheapest, the most profitable and wealthiest delivery channel for banking products. However, Pikkarainen et al. (2004), mentioned two fundamental reasons underlying electronic banking development and penetration, first, that banks get significant cost savings in their operation through e-Banking services which has proved that electronic banking channel is the cheapest delivery channel for banking products once established, secondly, that banks have reduced their branch networks and downsized the number of service staff, which has paved the way to self-service channels as quite many customers felt that branch banking took too much time and effort.

In Nigeria, the formal financial system provides services to about $35.0 \%$ of the economically active population while the remaining $65.0 \%$ are denied access to financial services. This $65.0 \%$ are often served by informal sector, through Non-Governmental Organization (NGO), considered as essential actors in achieving social and economic development in both developed and developing world (Sharma \& Zang, 2012). Agribusiness finance is very significant in developing countries because it can potentially serve as an enabler of inclusive growth and poverty reduction, productivity enhancement, improved income for agribusinesses operators, and overall balanced regional development. There is wide spread consensus that access to finance, particularly bank financing, can radically transform the outlook and performance of the SME sector, especially in the developing countries. For example, a number of studies including firm-level data from the World Bank over the years, show that inadequate financing is a greater obstacle for SME's than it is for large firms, particularly in the developing world, and that inaccessibility to finance constrains the growth of the SME sector more than that of large companies (The World Bank, 2018). For many agribusinesses, access to credit can readily support investments in productive operations, allow for the adoption of latest technologies and the scale-up of production activities to enhance productivity 
and competitiveness and increase profitability.

Agribusinesses and their value chain actors usually need a comprehensive suite of well-crafted financial services and products to improve their overall productivity and growth. Aggregators, processors, and marketers of agricultural commodities also need credit to undertake product transformation and other downstream value-adding activities (Stephen and Hayford, 2015). Although, the major constraints that limit the adoption of e-banking among business owners such as agro-entrepreneurs include poor network access, lack of trust due to network error, location, difficulties in handling electronic devices such as android phones, laptops, level of knowledge about the latest technology and poor delivery response as experienced in majority of Nigeria banks (Khan, 2007).

Theoretical Framework on behavioural changes and cognitive learning theories guide this study. Behavioural learning theories focus on the observable changes people experience once they have been exposed to a technology innovation, thereby highlighting their responses once they have adopted the technology. On the other hand, cognitive learning theories focus on how people adopt technologies, which includes their problem solving ability. These theories are useful to understand the usages of electronic banking as a technological innovation. Technological innovations enable businesses to introduce new ideas or creations in the marketplace (Rogers, 1965). In many cases, these innovations update an existing product or service by co-existing with surviving technology. However, technological innovation may supersede existing technology by involving an incremental or radical invention (Gan et al, 2006). Often, businesses will link with other organizations to generate technological innovations by generating new techniques

\section{A. Objectives of the Study}

Specifically, this study was designed to:

i. describe the socio-economic characteristics of Agro entrepreneurs in Obio/Akpor Local Government Area

ii. identify the various electronic banking products accessed by Agro entrepreneurs in Obio/Akpor LGA.

iii. examine the determinants of access to electronic banking among agro entrepreneurs in the study area.

iv. examine constraints to accessing electronic banking products among agro-entrepreneurs in the study area

\section{B. Hypothesis of the Study}

The study was guided by the following hypothesis:

HO: There is no significant relationship between socio-economic factors of agro- entrepreneurs and access to electronic banking in Obio/Akpor LGA.

\section{MATERIALS AND METHOD}

The study area was Obio-Akpor local government area of Rivers State. it is located in the metropolis of Port Harcourt, one of the major centres of economic activities in Nigeria, and one of the major cities of the Niger Delta. It is comprised of about 62 localities. The local government area covers 260 $\mathrm{km} 2$ and at the 2006 Census held a population of 464,789 .
Obio-Akpor has its headquarters at Rumuodomaya. The original indigenous occupants of the area are the Ikwerre people. Obio-Akpor is bounded by Port Harcourt (local government area) to the south, Oyigbo to the east, Ikwerre to the north, and Emohua to the west, and the population of this study comprised of Agro-entrepreneurs whose businesses were located within Obio-Akpor local government area of Rivers state.

A two-stage sampling procedure was employed in the selection of the respondents for this study. The first stage was a purposive selection of four communities, (Choba, Alakahia, Rumuokoro and Mgbuoba) based on high concentration of economic activities which were agro- based and availability of financial institutions. The second stage was a purposive selection of 20 farmers that were accessing electronic banking products, and 20 that were not accessing electronic banking products from each community. That made it a total of 80 of them that are accessing electronic banking products, and another 80 that were not. Making it a total of 160 agro entrepreneurs for the entire study.Primary data for the study were collected from agro-entrepreneurs by the use of two sets of structuredquestionnaires, one set was for agro entrepreneurs who were accessing electronic banking products and the second set for those that were not accessing electronic banking products.

\section{A. Model specification for Binary Logit}

Binomial logistic regression model was used given that the dependent variable is dichotomous: 0 when an agro-entrepreneur is having no access to electronic banking and 1 when having access to e-banking. Predictor variables are a set of socio-economic indicators of the agro-entrepreneur. They contain both dichotomous and continuous variables. Let $\mathrm{Pj}$ denote the probability that the $\mathrm{j}$-th agro-entrepreneur is having access to electronic banking. We assumed that $\mathrm{Pj}$ is a Bernoulli variable and its distribution depended on the vector of predictors $\mathrm{X}$, so that:

$$
\begin{gathered}
\operatorname{Pj}(\mathrm{X})=\mathrm{e} \alpha+\beta \mathrm{X} \\
1+\mathrm{e} \alpha+\beta \mathrm{X}
\end{gathered}
$$

The logit function estimated was then written as:

$\ln \{\mathrm{Pj} /(1-\mathrm{Pj})\}=\alpha+\sum \mathrm{I} \beta \mathrm{iXij}$

The logit variable $\ln \{\mathrm{Pj} /(1-\mathrm{Pj})\}$ is the natural $\log$ of the odds in favour of the agro-entrepreneur having access to internet banking.

The binary logit model estimated is specified as follows:

$\mathrm{Cij}=\beta 0+\beta 1$ age $+\beta 2$ maristat $+\beta 3$ edu $+\beta 4$ buzex + $\beta 5$ intacc $+\beta 6$ device $+\beta 7$ ease $+\beta 8$ rely $+\beta 9$ use + $\beta 10$ comp $+\beta 11 \mathrm{sec}+\mathrm{u}$

To estimate the above model, binary logit technique was used. The dependent variable for the logit model takes the binary form $(\mathrm{p}=\mathrm{Cij})$, which has probability equals to 1 if the agro-entrepreneur is having access to electronic banking products, and 0 otherwise. The coefficient estimates of $\beta$ give the change in the log-odds (logarithm of relative probabilities) of the outcome-here $=1-$, for a one unit increase in the independent variable, holding all other independent variables constant. Logit regressions are estimated using Maximum Likelihood (ML) rather than OLS. ML calculates coefficient estimates that maximize the likelihood of the sample data set being observed. 
$\mathrm{Cij},=$ Dummy $=1$ if the agro-entrepreneur is having access to electronic banking products, and 0 otherwise.

$$
\begin{aligned}
& \text { X1 }=\text { Age (Years) } \\
& \text { X2 = Marital status } \\
& \text { X3 = Educational status } \\
& \text { X4 = Business experience (Years) } \\
& \text { X5 = Internet access (Dummy; Yes }=1, \mathrm{No}=0 \text { ) } \\
& \text { X6 = Owns ICT device (Yes }=1, \mathrm{No}=0 \text { ) } \\
& \text { X7 = Ease of use (Dummy; Yes }=1, \mathrm{No}=0) \\
& \text { X8 = Reliability (Dummy; Yes }=1, \mathrm{No}=0 \text { ) } \\
& \text { X9 = Usefulness (Dummy; Yes }=1, \mathrm{No}=0)
\end{aligned}
$$

$\mathrm{X} 10=$ Compatibility (Dummy; $\mathrm{Yes}=1, \mathrm{No}=0$ )

$\mathrm{X} 11=$ Security risk ( Dummy; Yes $=1, \mathrm{No}=0$ ) $\mathrm{u}=$ stochastic error term

\section{Results AND Discussion}

\section{A. Socio- Economic Characteristics of Agro-Entrepreneurs}

The Socio-Economic Characteristics Of The Respondents Were Summarized In Table 1 Below.

Table 1: Socio-Economic Characteristics Of Agro Entrepreneurs

Socio-Economic Characteristicsfrequency $(\mathrm{N}=120)$

\section{Percentage $(\%)$}

\section{Gender}

Male

Female

53

67

Age

21-30

$31-40$

$41-50$

$51-60$

$61-70$

Marital Status

Single

Married

Widowed

\section{Educational Status}

Primary

Secondary

Tertiary

\section{Household Size}

1-5

6-10

$11-15$

Farming Status

Part Time

Full Time

Enterprise Type

Crop Farming

Livestock Farming

Fish Farming

Agro Processing

Agro Marketing

Agro Marketing/Crop Farm

Agro Marketing/Livestock Farm

Agro Marketing/Fish Farm

\section{Business Experience}

1-8

9-16

$17-24$

25-32

\section{5}

41

38

12

4

41

68

11

17

66

\begin{tabular}{|c|c|}
\hline 55 & 45.8 \\
\hline 61 & 50.8 \\
\hline 4 & 3.3 \\
\hline 56 & 46.7 \\
\hline 64 & 53.3 \\
\hline 13 & 10.8 \\
\hline 33 & 27.5 \\
\hline 18 & 15.0 \\
\hline 4 & 3.3 \\
\hline 39 & 32.5 \\
\hline 5 & 4.2 \\
\hline 4 & 3.3 \\
\hline 4 & 3.3 \\
\hline 74 & 61.7 \\
\hline 32 & 26.7 \\
\hline 7 & 5.8 \\
\hline 7 & 5.8 \\
\hline 50 & 41.7 \\
\hline 33 & 27.5 \\
\hline 13 & 10.8 \\
\hline 16 & 13.3 \\
\hline 8 & 6.7 \\
\hline
\end{tabular}

37

44.2

55.8

20.8

34.2

31.7

10.0

3.3

Field Survey (2019)

The result showed a slightly higher ratio of females $(55.8 \%)$ to males (44.2\%). About $34.2 \%$ of the respondents were in the age bracket $31-40$ and $31.7 \%$ in the age bracket 41-50.This indicates that the respondents were in the middle and active ages of production. Married individuals were the most dominant with a percentage of $56.7 \%$, followed by the singles with a percentage of $34.2 \%, 9.2 \%$ of the respondents were widowed .A breakdown of the educational status of the 
respondents showed that $14.2 \%$ attained primary education, $55.0 \%$ attained secondary education and $30.8 \%$ attained tertiary education. About $45.8 \%$ had a household size of $1-5$, $3.3 \%$ and $50.8 \%$ had a household size of $11-15$ and $6-10$ respectively with the household size of 6-10 being the majority in the study. Full time agro-entrepreneurs (53.3\%) are the most dominant in the study while part time agro-entrepreneurs $(46.7 \%)$ are less dominant. About $10.8 \%$ of the respondents were into crop farming, $27.5 \%, 15.0 \%$ and $3.3 \%$ were livestock farmers, fish farmers and agro produce processors respectively. Agro-product marketers (32.5\%) were the majority in the study. About $4.2 \%, 3.3 \%$ and $3.3 \%$ had combined enterprises.

\section{B. Electronic banking products and services accessed by} agro-entrepreneurs

The response of electronic banking products accessed by Agro-entrepreneurs is presented in Figure 1below.

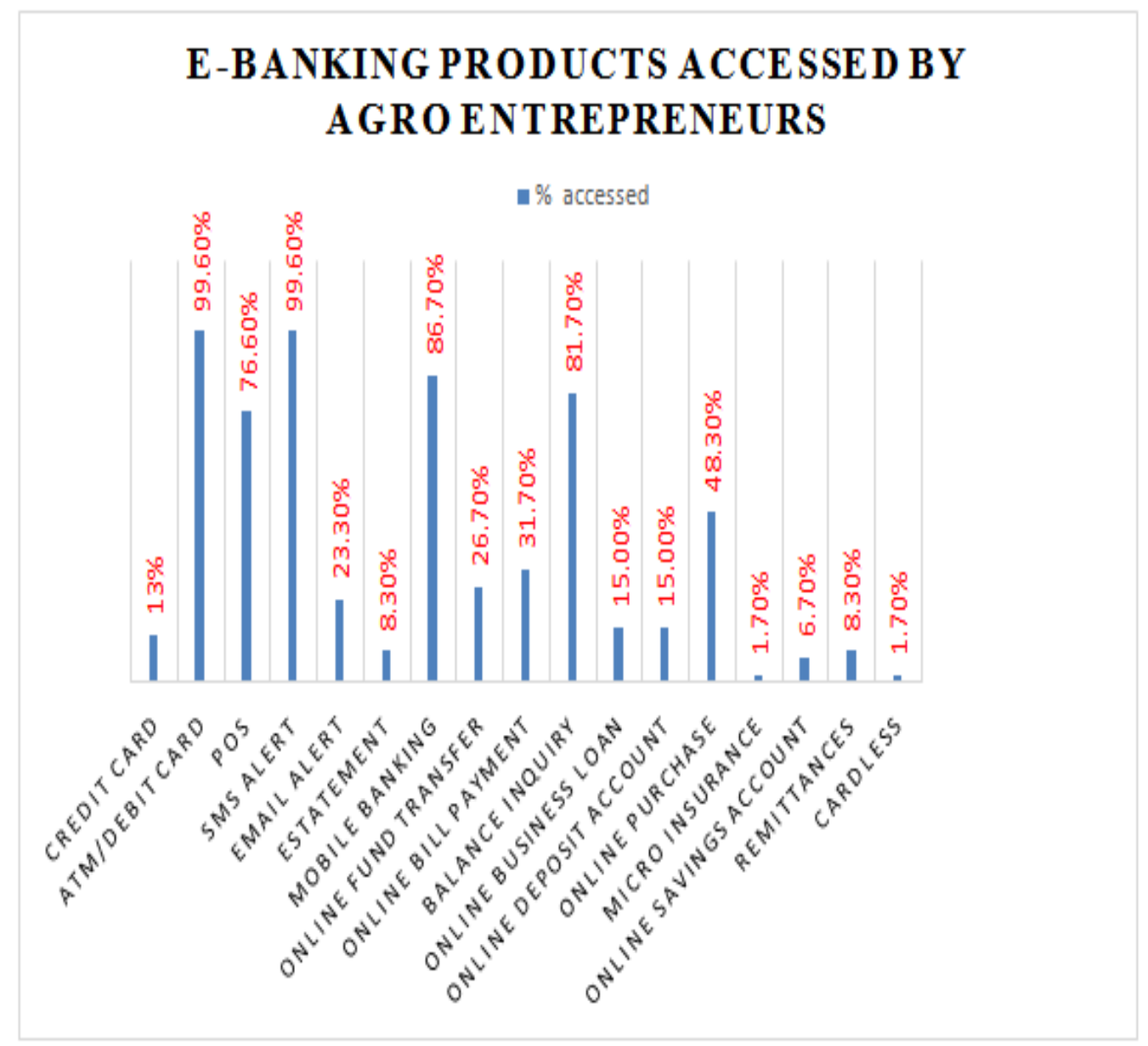

Fig 1: E-banking products accessed by Agro-entrepreneurs

Majority (99.6\%) of the respondents indicated accessing ATM/Debit cards. This agrees with the report of EFINA (2014) who stated that $76.2 \%$ of banked population in Nigeria have ATM/Debit cards.SMS alert services (99.6\%) were also highly accessed by the respondents. Majority of the agro-entrepreneurs indicated to be accessing mobile banking $(86.7 \%)$, POS (76.6\%) and Balance inquiry (81.7\%). Results from the figure above also showed that the respondents moderately accessed the following e-banking products; Email alert $(23.3 \%)$, Online fund transfer $(26.7 \%)$, Online bill payment $(31.7 \%)$, Online purchase $(48.3 \%)$. The least accessed e-banking services include; E statement (8.3\%), Online business loan $(15.0 \%)$, and Online deposit account (15.0\%), Online savings account (6.7\%), Micro insurance (1.7\%), Remittances (8.3\%) and Cardless banking (1.7\%). This is line with the findings of EFINA (2016) who reported that Micro insurance and Online savings account are least accessed by banked population in Nigeria.

Determinants of access to electronic banking by agro-entrepreneurs 
Table 2: Determinants of access to Electronic banking

\begin{tabular}{|c|c|c|c|c|}
\hline Variables & Coeff & Std.Error & Wald & P-Values \\
\hline $\operatorname{Age}\left(X_{1}\right)$ & $0.278^{*}$ & 0.164 & 2.870 & 0.090 \\
\hline Marital status $\left(\mathbf{X}_{2}\right)$ & -0.534 & 0.447 & 1.425 & 0.233 \\
\hline Educational status $\left(\mathbf{X}_{3}\right)$ & 21.413 & 5268.996 & 0.000 & 0.997 \\
\hline Business experience $\left(\mathbf{X}_{4}\right)$ & $-0.903 * *$ & 0.454 & 3.951 & 0.047 \\
\hline Internet access $\left(\mathbf{X}_{5}\right)$ & $5.242 * *$ & 2.082 & 6.340 & 0.012 \\
\hline Own ICT device $\left(X_{6}\right)$ & 15.788 & 8462.411 & 0.000 & 0.999 \\
\hline Ease of use $\left(\mathbf{X}_{7}\right)$ & $1.513^{*}$ & 0.856 & 3.127 & 0.077 \\
\hline Reliability $\left(\mathbf{X}_{\mathbf{8}}\right)$ & $1.767^{* * *}$ & 0.731 & 5.852 & 0.016 \\
\hline Usefulness $\left(\mathbf{X}_{\mathbf{9}}\right)$ & -1.308 & 0.856 & 2.334 & 0.127 \\
\hline Compatibility $\left(\mathbf{X}_{10}\right)$ & 0.173 & 0.612 & 0.080 & 0.777 \\
\hline $\begin{array}{l}\text { Perceived security risk } \\
\left(\mathbf{X}_{11}\right)\end{array}$ & $-3.263 *$ & 1.795 & 3.303 & 0.069 \\
\hline Constant & $-36.221 * * *$ & 9397.296 & 0.000 & 0.000 \\
\hline Omnibus Test Chi Square & 146.859 & & & \\
\hline Prob>chi square & 0.000 & & & \\
\hline Nagelkerke R-square & 0.941 & & & \\
\hline
\end{tabular}

Source: Field survey 2019. *** Significant at $1 \%$ level, $* *$ Significant at 5\% level, * Significant at $10 \%$ level.

A binary logistic regression was carried out to ascertain the determinants of access to e-banking as presented in Table 3 above. The dependent variable (access to electronic banking) was captured as Accessed $=1$, did not access $=0$. The model is statistically significant indicating that the explanatory variables estimated reliably distinguished between agro-entrepreneurs that accessed e-banking services and those who did not (Chi square $=146.859, \mathrm{P}=0.000$ ), Nagelkerke R-square value is 0.941 indicating that $94.1 \%$ of the variation in the access of electronic banking products were explained by the combined effect of all the independent variables in the model specified. Out of the eleven examined explanatory variables in the model, six factors ; Age, Business experience, Internet access, Reliability, Perceived security risk, Ease of use were statistically significant in accessing electronic banking services. The coefficient of Age is positive and significant at $10 \%$. This suggest that Age is a factor for accessing e-banking. Respondents advanced in age are more likely to access e-banking products. The coefficient of Reliability is also positive and significant at 5\% level of probability which implies that Reliability is a major determinant of e-banking products to be reliable. Perceived security risk is significant at $10 \%$ with a negative coefficient
(-3.263). This implies that agro-entrepreneurs who are averse to security risk are less likely to access electronic banking products. This is in line with the findings of Fadare (2016) who reported that security risk negatively influence intension towards the use of electronic banking. Business experience is statistically significant at $5 \%$ with a negative coefficient $(-0.903)$. This suggests that agro-entrepreneurs that have been in the business for a long time are less likely to access e-banking. This may be due to people who are traditionalist, who cling to old habits and usually have difficulty embracing innovations. The study reveals that agro entrepreneurs who have internet access are more likely to access electronic banking. This conforms to the findings of Vijay (2011) who stated that internet access is a major determinant of internet banking adoption in India. The coefficient of Ease of use is positive and significant at $10 \%$ suggesting that the respondents find e-banking products easy to operate without any mental and physical stress.

Constraints to accessing electronic banking services and products

The results on the constraints to access of e-banking products and services are summarized in Fig. 2 below. 


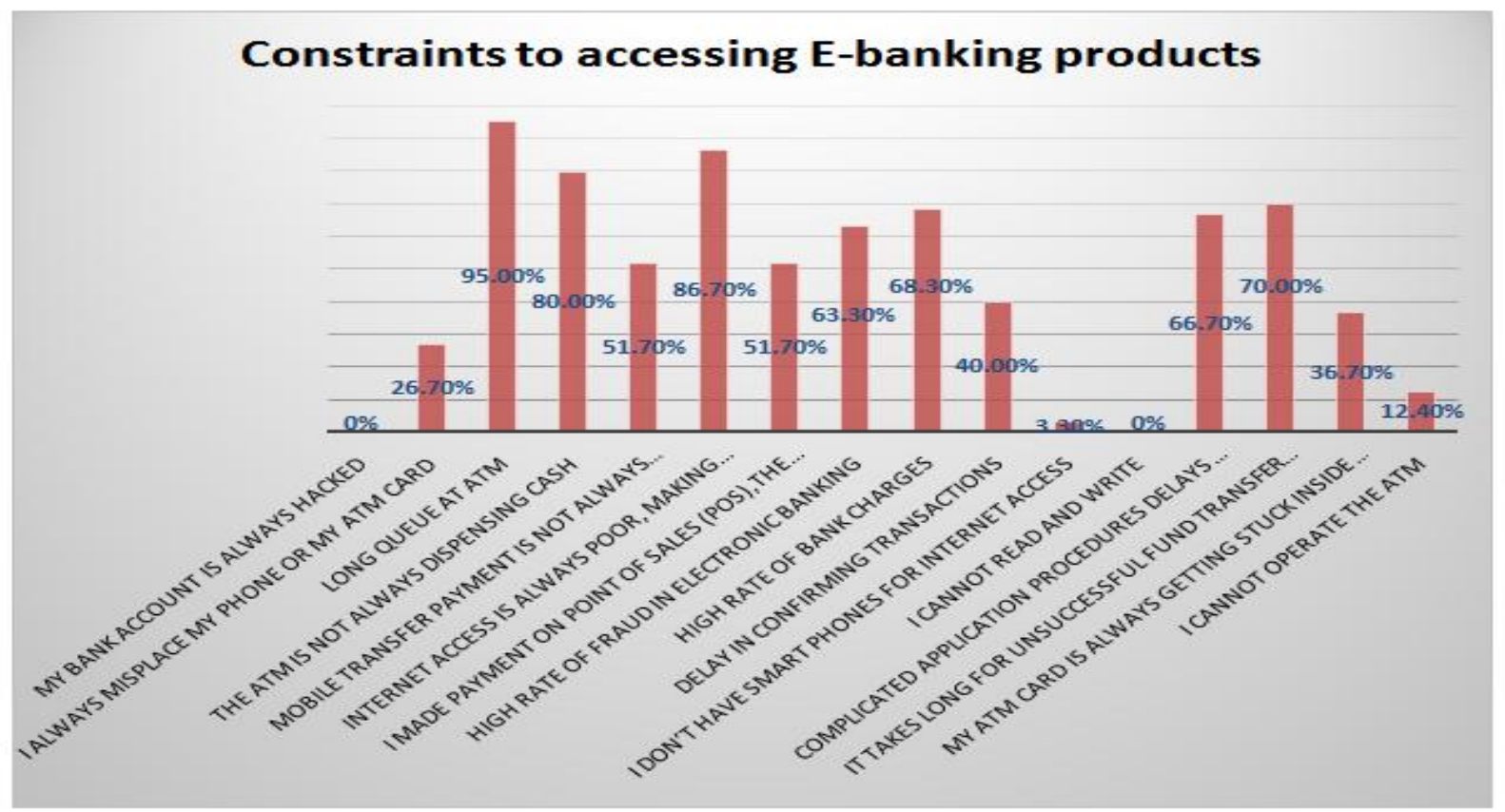

Fig 2: Constraints to accessing E-banking products

The study revealed that majority $(95.0 \%)$ face long queue at ATM stands .About $51.7 \%$ indicated that they made payment through point of sales (POS) terminal, the transaction wasn't approved, yet money was deducted from their account.63.3\% revealed that they had experienced fraudulent activities in e-banking. Majority of the respondents have experienced poor internet access (86.7\%), delay of return of unsuccessful fund transfer (70.0\%) as well as the ATM not dispensing cash $(80.0 \%) .68 .3 \%$ of the respondents complained of high rate of bank charges on transactions made, $66.7 \%$ also complained of complicated application procedures which delays their access to e-banking products as well as their mobile transfer payment not always being successful (51.7\%). Only a few had issues with the following; Misplaced ATM card (26.7\%), ATM card getting stuck inside the ATM (36.7\%) and not being able to operate the ATM (12.4\%).

\section{CONCLUSION}

From the preceding discussions, it can be observed that Age, Business experience, Perceived security risk, Reliability, Ease of use and Internet access are major determinants of access to electronic banking among agro-entrepreneurs. Long queue at ATM, Poor internet access, ATM not always dispensing cash, High rate of bank charges, Complicated application procedures for e-banking and High rate of fraud in e-banking are the major problems faced by agro-entrepreneurs in accessing electronic banking products, and this limits productivity. The study recommends strong security architecture for better and stronger bank website management in order to reduce fraudulent activities on bank customer's account. Money should be readily available on the ATM to reduce the problem of ATM not always dispensing cash at moments when entrepreneurs need to access these funds. Electronic banking application procedures should be made less complicated

\section{REFERENCES}

[1]Abdou, H.A. John \&Adewunmi, Paul (2014). An investigation of risk management practices in electronic banking: The case of the UK banks. Accessible athttps://www.sc.com/ng/electronic-banking-terms-conditions.html, 2018. Accessed on 18th January, 2019.

[2]Enhancing Financial Innovation and Access (EFInA) 2014. Access to Financial Services in Nigeria 2014 Survey. Retrievable from http://www.efina.org.ng/media-centre/news. (Accessed 4 June 2018)

[3] Enhancing Financial Innovation and Access (EFInA) ,2016. Access to Financial Services in Nigeria 2016 Survey. Retrievable from http://www.efina.org.ng/media-centre/news(Accessed 16 June 2018)

[4]Fadare, O.A. (2016).A Survey on Perceived Risk and Intention of Adopting Internet Banking.Journal of Internet Banking and Commerce 21(1), 1-21

[5]Gan, C., Clemes, M., Limsombunchai, V., and Weng, A.( 2006) A Logit Analysis of Electronic Banking in New Zealand, International Journal of Bank Marketing 24(6), 360- 383

[6]Khan, M. (2007). Consumer Behaviour. (2nd ed.) India: New Age International.

[7]Pikkarainen, T., Pikkarainen, K., Karjaluoto, H., and Pahnila, S. (2004). Consumer acceptance of online banking: An extension of the technology acceptance model. Internet Research, 14(3), 224-235.

[8]Rogers, E. M. (1995). Diffusion of innovations (1st ed.). New York: The Free Press Sathye

[9] Sharma M, \& Zhang J. (2012). Analysis of prospects for delivering agricultural finance for sustainable development, expanding agricultural market opportunities and promotion of disadvantaged small farmers and MSMEs: Workshop on Enhancing Exports' Competitiveness Though Value Chain Finance. Background paper series. 1-7.

[10] Sharp, J.H. (2007). 'Development, extension, and application: a review of the Technology Acceptance Model', Information Systems Education Journal, 5(9): 3-11.

[11] Stephen, O.,\&Hayford A. (2015). Determinants of Access to Credit by Agribusiness Operators in the Kumasi Metropolis, Ghana. American Journal of Experimental Agriculture6 (5): 333-346. Article no.AJEA.2015.092.

[12] Tan, M, \& Teo, T. H. (2000). "Factors affecting the adoption of Internet banking. Journal of the Association of Information Systems, Vol.1, pp. $1-42$.

[13] World Bank (2018).World Bank Enterprise analysis surveys. Washington DC.

[14] Vijay MK, 2011. Determinants of Internet Banking Adoption: An Empirical Evidences from Indian Banking, Indian Journal of Commerce and Management Studies 2(1): 4-25 


\section{PROFILE OF DR UGWUJA VIVIAN.C}

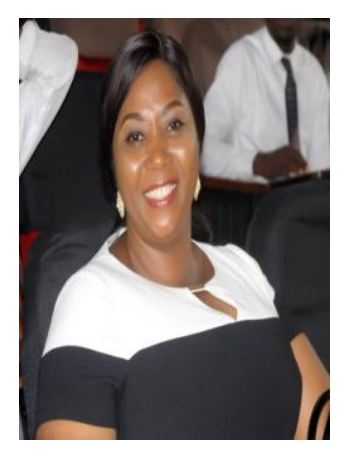

Dr Ugwuja Vivian Chinelo is a Senior Lecturer in theDepartment of Agricultural Economics and Extension, University of Port-Harcourt, Rivers State, Nigeria. She obtained her B.Agric (Animal Science) from University of Nigeria, Nsukka and was the best graduating student for the year 2001. She obtained her M.Sc in Agricultural Economics from Rivers State University of Science and Technology in 2010, and her doctorate degree in Agricultural Finance and Project Analysis from the University of Nigeria, Nsukka in 2016.

Her research interests include rural development, microfinance, digital finance and cybersecurity. She has practical experience with community youth and women cooperatives where she has been involved in enterprise development for the youths and women. She is currently the chairperson, UNIPORT CHOBA SEEFOR/Fadama Community Association, a World Bank assisted project. She was a Postdoctoral research fellow in Cybersecurity from 2017-2019, awarded and sponsored by AXA Research Fund Group, honoured to be the first Nigerian awardee

She has published a chapter in a book, many journals (national and international) and conference proceedings, she has attended conferences, workshops and trainings. She is a member of Nigerian Association of Agricultural Economists (NAAE) and Organization for Women in Science for the Developing World (OWSD). She also belongs to so many committees both in the university and religious bodies PROFILE OF UMEH FRANCISCA .O

Mrs Umeh Francisca .O obtained her B.Agric (Agricultural Economics) from the University of Port Harcourt, Rivers State, Nigeria. She is happily married with children 